https://journal-computing.org/index.php/journal-cisa/index

\title{
Analisis Resiko Aplikasi Sistem Informasi Pengelolaan Data Umat Menggunakan ISO 31000 (Studi Kasus: Gereja Katolik Santo Paulus Miki Salatiga)
}

\author{
Diane Junianti ${ }^{1}$, Charitas Fibriani ${ }^{2}$ \\ ${ }^{1}$ Sistem Informasi, Universitas Kristen Satya Wacana, Salatiga, Indonesia. \\ Email: 1682017405@student.ulsw.edu, 22charitas.fibriani@uksw.edu.
}

\begin{abstract}
The People's Data Management Information System is an information system that manages people's data from the diocese, parish, regional, to environmental levels. This application is used to input data, update data, and delete data, the application of the Ummah Data Management Information System has risks that will hinder the application, such as unstable internet connections, the latest data and the readiness of human resources who operate the system. The purpose of the research is to minimize the possibility of risk, so ISO 31000 is used to determine the impact of risk, the level of risk, and the treatment of risk needed in a company or organization in conducting the analysis. It is hoped that the existence of ISO 31000 can overcome the risks that will occur now and in the future.
\end{abstract}

Keywords: NIST, Risk Assessment, Risk Management.

\section{PENDAHULUAN}

Pada masa modern ini berkembangnya Teknologi yang sangat pesat membuat hampir seluruh aspek bergantung kepada teknologi, seperti: media sosial, internetan. Internet sangat membantu dalam menjalankan tugas dan tanggungjawab terutama dalam menggembangkan sebuah organisasi atau perusahaan terutama di Gereja Katolik Santo Paulus Miki Salatiga [1]. Gereja Santo Paulus Miki Salatiga merupakan organisasi yang berkembang dalam bidang keagamaan, aplikasi Sistem Informasi Pengelolaan Data Umat merupakan bagian dari Sistem Pendataan Umat 
Vol. 2, No. 2, May 2021 e-ISSN: 2775-2496

https://journal-computing.org/index.php/journal-cisa/index

Keuskupan Agung Semarang (KAS) yang dikembangkan sejak awal tahun 2020 oleh Tim IT KAS untuk mengelola data umat mulai dari Keuskupan, Paroki, Wilayah, sampai ke tingkat Lingkungan. Adanya aplikasi ini dapat membantu dalam mengumpulkan berbagai berkas terkait dengan pelayanan gereja mulai dari input data, update data dan delete data serta yang berhubungan dengan pendataan umat.

Manajemen risiko merupakan proses identifikasi untuk mengukur seluruh resiko dalam mengelola bisnis atau proyek sehingga dalam menghasilkan sebuah keputusan agar tercapainya sebuah sasaran dalam menjalankan proses bisnis, ada beberapa tahap dari manajemen risiko yaitu identifikasi resiko, analisis, dan penilaian resiko [2]. Pada tahap manajemen resiko diperlukannya pengelolaan informasi terkait dengan kepercayaan antar pihak manajemen dengan karyawan, kepercayaan merupakan elemen yang penting dalam membangun sebuah keamanan informasi di dalam lingkup teknologi informasi dengan begitu mempermudah dalam menerapkan perilaku keamanan informasi didalam perusahaan atau organisasi [3].

Alasan dari penerapan aplikasi Sistem Informasi Pengelolaan Data Umat dilakukan karena kebutuhan umat yang semakin meningkat setiap tahunnya dan tidak menutup kemungkinan dapat menyebabkan proses bisnis terganggu atau terhenti, ini salah satu cara proses bisnis berjalan dengan lancar adalah melalui ISO 31000 agar dapat memahami resiko saat ini dan kemungkinan resiko di masa depan. Kemungkinan resiko mengakibatkan terganggu atau berhentinya suatu proses bisnis, membuat cara agar proses bisnis dapat berjalan dengan lancar adalah melalui ISO 31000 untuk dapat melihat kemungkinan resiko apa saja yang akan terjadi saat ini dan yang akan datang. Mengatasi permasalahan maka dilakukannya analisis dampak resiko, level resiko, dan perlakuan terhadap risiko digunakannya metode ISO 31000 karena sesuai dengan kebutuhan yang diperlukan didalam organisasi atau perusahaan saat ini dan yang akan datang. Penelitian terdahulu tentang "Analisis teknologi informasi menggunakan ISO 31000" yang dilakukan tahun 2020, aplikasi yang digunakan berfungsi untuk mencatat buku pinjaman, daftar buku yang tersedia, jumlah buku, jatuh tempo peminjaman dan daftar peminjaman. Nama dari aplikasinya adalah SINTESA, dimana menghasilkan 18 kemungkinan resiko yang akan mengganggu kinerja dari aplikasi SINTESA yang telah diteliti [4]. 


\section{Journal of Computer and Information Systems Ampera}

Vol. 2, No. 2, May 2021 e-ISSN: 2775-2496

https://journal-computing.org/index.php/journal-cisa/index

Pada tahun 2019 penelitian dilakukan di PT Serasa Autoraya tentang "analisis resiko SAP menggunakan Framework ISO 31000", menghasilkan 15 kemungkinan resiko yang menghambat terjadinya aplikasi. Hasil dari penelitian dapat membantu dalam menyusun dokumentasi terkait dengan manajemen resiko, kemungkinan terbesar dari hasil penelitian ada dua yaitu listrik dan koneksi internet yang sangat mengganggu aktivitas pada suatu perusahaan [5]. Penelitian tentang "analisis resiko website SWIFTS" pada Lembaga Penerbangan dan Antariksa Nasional (LAPAN) tahun 2017 yang menggunakan Framework 31000", tujuan dilakukannya penelitian adalah mengelola sebuah kemungkinan resiko untuk menghasilkan sebuah resiko secara optimal dengan melakukan pencegahan, penanganan, pemeliharaan terhadap aset pendukung dan hasil dari penelitian kemungkinan resiko tersebut menghasilkan 34 kemungkinan resiko [6].

Penelitian terdahulu tentang "Analisis resiko aplikasi teknologi informasi aplikasi Vcare pada PT Visionet Data Internasional menggunakan ISO 31000 tahun 2020, aplikasi Vcare berfungsi untuk pendaftaran layanan pengadaan mesin dan pedagang, kontrak layanan, mengelola service, dan penarikan mesin EDC (Electronic Data Capture), hasil dari penelitian tersebut menghasilkan 20 kemungkinan resiko yang dapat mengganggu berjalannya sebuah aplikasi Vcare [7]. ISO 31000 digunakan untuk mengidentifikasi peluang, ancaman, dan efektif dalam menganalisis kemungkinan resiko. Menerapkan prinsip pada kerangka kerja ISO 31000 dan mewujudkan manajemen tata kelola serta evaluasi kesiapan dari prinsip ISO 31000 bagi perusahaan atau organisasi [8].

Analisis manajemen risiko menggunakan ISO 31000 adalah mengelola risiko secara keseluruhan terutama pada pencegahan, penanganan serta perbaikan manajemen risiko yang telah diterapkan. Menyiapkan secara jelas teknis yang dilakukan agar terarah dan efektif dalam menjalankan proses bisnis [9].

Edisi pertama pedoman manajemen risiko ISO 31000 diterbitkan oleh Organisasi Internasional untuk Standardisasi tahun 2009 adalah framework yang mendasarkan manajemen melalui framework, konsep dan terminologi. Setelah itu dibuatnya pembaharuan dikarenakan tidak adanya sertifikasi di tahun 2009, sekarang menjadi versi ISO 31000: 2018, versi ini menyajikan visi yang lebih lengkap dan strategis untuk manajer, menentukan prinsip-prinsip dan metodologi yang digunakan lebih akurat sehingga dapat melindungi nilai institusi [10]. Harus adanya kerjasama 


\section{Journal of Computer and Information Systems Ampera}

Vol. 2, No. 2, May 2021 e-ISSN: 2775-2496

https://journal-computing.org/index.php/journal-cisa/index

untuk bisa menjalankan kerangka kerja yang telah diterapkan pada ISO 31000 yang melibatkan penerapan sistematis kebijakan, prosedur, kegiatan komunikasi, konsultasi, evaluasi, perlakuan, pemantauan, dan analisis. Kerangka kerja dari ISO 31000 membantu dalam mengambil keputusan dan pencapaian dalam mencapai tujuan yang telah direncanakan [11].

\section{METODE}

Framework ISO atau International Organization for Standardization (ISO) 31000, merupakan standar internasional yang menerapkan manajemen risiko. Tujuan dari framework ISO adalah untuk memberikan pedoman dan prinsip-prinsip manajemen risiko yang diakui oleh dunia. Pada gambar 1, menjelaskan kerangka kerja dari manajemen resiko. Berdasarkan International organization for Standardization (ISO 3100:2018), sebelum melakukan tahap 1 dan 2 tentukan dulu ruang lingkup, konteks dan kriteria manajemen. Terdapat 2 tahap pencarian informasi yaitu Risk Assessment (Penilaian Resiko) dan Risk Treatment (Perlakuan Risiko) [12].

Tahap pertama Risk Assessment ada 3 tahap: Risk Identifikasi ( Identifikasi Resiko) adalah usaha untuk mengetahui resiko-resiko yang akan timbul didalam keberlangsungannya perusahaan atau organisasi, Risk Analysis (Analisis Resiko) adalah mengetahui level resiko yang akan mengancam aset dan membangun strategi perusahaan atau organisasi dan Risk Evaluasi (Evaluasi Resiko) adalah membantu dalam pengambilan keputusan berdasarkan hasil analisis resiko serta memperbaiki kesalahan yang telah dilakukan sebelumnya[13].

Tahap kedua Risk Treatment (Perlakuan Risiko) adalah proses merubah risiko untuk menanggulangi kemungkinan resiko yang akan terjadi. Pada tahap 1 harus adanya komunikasi serta konsultasi terkait dengan analisis yang dilakukan selanjutnya tahap 2 memantau secara rutin kinerja dalam menganalisis serta langka apa saja yang dilakukan agar dapat berjalan dengan lancar proses bisnisnya, setelah dilakukannya semua tahap proses terakhir adalah perekaman dan pelaporan hasil analisis yang dilakukan [14].

Data yang didapatkan melalui salah satu staf yang mengelola IT di Paroki Santo Paulus Miki Salatiga, jenis data yang digunakan adalah kuantitatif, 


\section{Journal of Computer and Information Systems Ampera}

Vol. 2, No. 2, May 2021 e-ISSN: 2775-2496

https://journal-computing.org/index.php/journal-cisa/index

yang pertama melalui proses wawancara dari narasumber melalui via whatsapp dalam tahap wawancara membuat pertanyaan dalam word dikirim kepada narasumber dan dikirim kembali isi dari pertanyaan yang telah dibuat, tahap kedua adalah mengelola hasil dari wawancara untuk dijadikan sebuah analisis dengan mengikuti kerangka kerja dari ISO 31000:2018 [15].

\section{HASIL DAN PEMBAHASAN}

Pada tahap penilaian resiko Aplikasi Sistem Informasi Pengelolaan Data Umat dengan menggunakan analisis manajemen risiko 31000, ada 3 tahap yaitu: Identifikasi resiko, analisis resiko, dan evaluasi resiko. Tahap pertama yang dilakukan pada tahap penilaian risiko adalah identifikasi aset yang berhubungan dengan aplikasi Pendataan Umat Paroki Santo Paulus Miki Salatiga. Dengan melakukan wawancara dengan salah seorang staf IT pada aplikasi ini, proses identifikasi asset yaitu: Data, Software dan Hardware yang berhubungan dengan aplikasi.

Tabel 1. Identifikasi Aset Aplikasi Sistem Informasi Pengelolaan Data Umat

\begin{tabular}{cc}
\hline $\begin{array}{c}\text { Komponen Sistem } \\
\text { Informasi }\end{array}$ & $\begin{array}{c}\text { Aset Aplikasi Sistem } \\
\text { Informasi Pengelolaan Data } \\
\text { Umat }\end{array}$ \\
\hline Data & Data Umat, Data User \\
Software & Aplikasi Sistem Informasi \\
& Pengelolaan Data Umat \\
Hardware & Personal Computer, \\
& Server Database \\
\hline
\end{tabular}

Tabel 1 menjelaskan bahwa identifikasi aset aplikasi Pendataan Umat Paroki Santo Paulus Miki Salatiga menghasilkan Data, yang memiliki 2 aset yaitu Data Umat yang dikelompokan yaitu: nama, jenis kelamin, agama, pekerjaan, wilayah gereja, lingkungan gereja, NIK dan KK, Data User yaitu: nama lengkap dari data yang diinginkan. Software berbentuk Aplikasi Sistem Informasi Pengelolaan Data Umat dan hardware ada 2 aset yang pertama Personal computer yaitu: layar, keyboard, dan touchpad dan yang kedua Server database yaitu: mysql. Selanjutnya akan dilakukannya identifikasi kemungkinan-kemungkinan resiko yang akan menghambat 


\section{Journal of Computer and Information Systems Ampera}

Vol. 2, No. 2, May 2021 e-ISSN: 2775-2496

https://journal-computing.org/index.php/journal-cisa/index

berjalanya aplikasi Pendataan Umat Paroki Santo Paulus Miki Salatiga. Terdapat 3 faktor yaitu: faktor Alam/Lingkungan, Manusia dan Sistem Infrastruktur yang menghambat berjalannya aplikasi Pendataan Umat Paroki Santo Paulus Miki Salatiga. Dapat dilihat pada tabel 2 Identifikasi kemungkinan resiko.

Tabel 2. Identifikasi Kemungkinan Resiko

\begin{tabular}{lll}
\hline Faktor & ID & Kemungkinan Resiko \\
\hline Alam/Lingkungan & RE01 & Petir \\
& RE02 & Banjir \\
RE03 & Kebakaran \\
RE04 & Gempa bumi \\
Manusia & RE05 & Penyalahgunaan hak akses \\
& RE06 & Perubahan data umat \\
& RE07 & User interface aplikasi yang \\
& RE08 & Cylit dipahami \\
& RE09 & Pencrime \\
& & \\
& & \\
Sistem dan Infrastruktur perangkat/data \\
& RE11 & Overload \\
& Overheat \\
& RE12 & Koneksi jaringan \\
& RE13 & stabil \\
& RE14 & Koneksi jaringan terputus \\
& RE15 & Data corrupt \\
& RE16 & Backupfailure \\
& Kerusakan hardware \\
&
\end{tabular}

Tabel 2 menjelaskan tahap identifikasi resiko, ditemukan ada 16 kemungkinan-kemungkinan resiko yang berasal dari faktor alam/lingkungan yaitu: RE01 ada Petir, RE02 ada Banjir, RE03 ada Kebakaran, dan RE04 ada Gempa bumi. Yang berasal dari Manusia yaitu: RE05 ada Penyalahgunaan hak akses, RE06 ada Perubahan data umat, RE07 ada User interface aplikasi yang sulit dipahami, RE08 ada Cybercrime, RE09 ada Pencurian perangkat/data serta sistem dan infrastruktur yaitu: RE10 ada Overload, RE11 ada Overheat, RE12 ada Koneksi jaringan yang tidak stabil, RE13 ada Koneksi jaringan terputus, RE14 ada Data corrupt, RE15 ada Backup failure dan RE16 ada Kerusakan hardware. Yang 


\section{Journal of Computer and Information Systems Ampera}

Vol. 2, No. 2, May 2021 e-ISSN: 2775-2496

https://journal-computing.org/index.php/journal-cisa/index

menghambat Aplikasi Sistem Informasi Pengelolaan Data Umat Di Paroki Santo Paulus Miki Salatiga. Setelah mengetahui kemungkinan resiko dilakukan juga identifikasi dampak resikonya, dapat dilihat pada tabel Identifikasi dampak risiko.

Tabel 3. Identifikasi Dampak Risiko.

\begin{tabular}{|c|c|c|}
\hline ID & Kemungkinan Resiko & Dampak \\
\hline RE01 & Petir & $\begin{array}{l}\text { Kerusakan } \\
\text { infrastruktur } \\
\text { perusahaan }\end{array}$ \\
\hline RE02 & Banjir & $\begin{array}{l}\text { Menghambat aktivitas } \\
\text { bisnis perusahaan }\end{array}$ \\
\hline RE03 & Kebakaran & $\begin{array}{l}\text { Kerusakan } \\
\text { infrastruktur dan } \\
\text { aktivitas perusahaan } \\
\text { terhenti }\end{array}$ \\
\hline RE04 & Gempa Bumi & $\begin{array}{l}\text { Aktivitas terhenti dan } \\
\text { kerusakan } \\
\text { infrastruktur } \\
\text { perusahaan }\end{array}$ \\
\hline RE05 & $\begin{array}{l}\text { Penyalahgunaan hak } \\
\text { akses }\end{array}$ & $\begin{array}{l}\text { Data user di salah } \\
\text { gunakan }\end{array}$ \\
\hline RE06 & Perubahan data umat & $\begin{array}{l}\text { Sulit mencari data } \\
\text { yang diinginkan }\end{array}$ \\
\hline RE07 & $\begin{array}{l}\text { User interface aplikasi } \\
\text { yang sulit dipahami }\end{array}$ & $\begin{array}{l}\text { User sulit mengerti } \\
\text { cara penggunaan } \\
\text { aplikasi }\end{array}$ \\
\hline RE08 & Cybercrime & $\begin{array}{l}\text { Bocornya } \\
\text { data/informasi gereja }\end{array}$ \\
\hline RE09 & $\begin{array}{l}\text { Pencurian } \\
\text { perangkat/data }\end{array}$ & $\begin{array}{l}\text { Perusahaan akan } \\
\text { mengalami kerugian }\end{array}$ \\
\hline RE10 & Overload & $\begin{array}{l}\text { Jika database penuh } \\
\text { maka akan berhenti } \\
\text { secara tiba-tiba }\end{array}$ \\
\hline RE11 & Overheat & $\begin{array}{l}\text { Hardware tidak dapat } \\
\text { digunakan dan tidak } \\
\text { bekerja secara optimal } \\
\text { jika suhunya } \\
\text { mengalami panas } \\
\text { secara terus menerus }\end{array}$ \\
\hline
\end{tabular}


Journal of Computer and Information Systems Ampera

Vol. 2, No. 2, May 2021 e-ISSN: 2775-2496

https://journal-computing.org/index.php/journal-cisa/index

\begin{tabular}{|c|c|c|}
\hline \multirow[t]{3}{*}{ RE12 } & \multirow[t]{3}{*}{$\begin{array}{l}\text { Koneksi jaringan tidak } \\
\text { stabil }\end{array}$} & $\begin{array}{l}\text { Menghambat akses } \\
\text { aplikasi Pendataan }\end{array}$ \\
\hline & & Umat Paroki Santo \\
\hline & & Paulus Miki Salatiga \\
\hline \multirow[t]{3}{*}{ RE13 } & Koneksi jaringan terputus & $\begin{array}{l}\text { Gagal melakukan } \\
\text { update pada aplikasi }\end{array}$ \\
\hline & & Pendataan Umat \\
\hline & & $\begin{array}{l}\text { Paroki Santo Paulus } \\
\text { Miki Salatiga }\end{array}$ \\
\hline RE14 & Data corrupt & $\begin{array}{l}\text { Perusahaan tidak } \\
\text { mendapatkan } \\
\text { yang valid }\end{array}$ \\
\hline RE15 & Backup failure & $\begin{array}{l}\text { Data yang diterima } \\
\text { tidak akan lengkap }\end{array}$ \\
\hline RE16 & Kerusakan Hardware & $\begin{array}{l}\text { Aktivitas perusahaan } \\
\text { akan terhambat dan } \\
\text { harus memindahkan } \\
\text { data ke hardware yang } \\
\text { baru }\end{array}$ \\
\hline
\end{tabular}

Tabel 3 menjelaskan tentang Identifikasi Dampak Risiko pada kemungkinan resikonya yaitu: Petir mengakibatkan kerusakan infrastruktur seperti bangunan rusak dan listrik yang mati atau konslet, banjir menyebabkan aktivitas bisnis perusahaan terhenti, kebakaran mengakibatkan kerusakan infrastruktur dan aktivitas perusahaan terhenti seperti gedung terbakar sehingga harus dilakukan perhentian kerja untuk sementara sampai ada kebijakan dari perusahaan atau organisasi, gempa bumi menyebabkan aktivitas terhenti dan kerusakan infrastruktur perusahaan seperti tidak ada jam kerja sampai ada kebijakan dari perusahaan dan gedung rusak, penyalahgunaan hak akses mengakibatkan data user disalah gunakan seperti digunakan untuk mencari keuntungan personal, perubahan data umat menyebabkan sulit mencari data yang diinginkan seperti nama, jenis kelamin, agama, pekerjaan, wilayah gereja, lingkungan gereja, NIK dan KK, user interface aplikasi yang sulit dipahami mengakibatkan user sulit mengerti cara penggunaan aplikasi seperti tidak adanya pelatihan dalam penggunaan aplikasi dan desain dari user interface yang tidak bisa dibaca oleh user.

Cybercrime menyebabkan bocornya data/informasi gereja seperti identitas umat, pencurian perangkat/data mengakibatkan perusahaan 


\section{Journal of Computer and Information Systems Ampera}

Vol. 2, No. 2, May 2021 e-ISSN: 2775-2496

https://journal-computing.org/index.php/journal-cisa/index

akan mengalami kerugian seperti bocornya identitas, overload akan berdampak sangat fatal jika database penuh maka akan berhenti secara tiba-tiba sehingga terhambatnya proses bisnis perusahaan atau organisasi, overheat menyebabkan hardware tidak dapat digunakan dan tidak bekerja secara optimal jika suhunya mengalami panas secara terus menerus, koneksi jaringan tidak stabil akan menghambat aks es aplikasi Sistem Informasi Pengelolaan Data Umat, koneksi jaringan terputus mengakibatkan gagal melakukan pembaruan pada aplikasi Sistem Informasi Pengelolaan Data Umat, data corrupt menyebabkan perusahaan tidak mendapatkan data yang lengkap sehingga menghambat berjalannya proses bisnis perusahaan atau organisasi, backup failure menyebabkan data yang diterima tidak lengkap akan mengakibatkan terhambatnya proses bisnis, dan kerusakan hardware mengakibatkan aktivitas perusahaan akan terhambat dan harus memindahkan data ke hardware yang baru sehingga membutuhkan waktu untuk bisa memindahkan data. Serta dampak yang dilakukan, selanjutnya tahap analisis resiko.

Setelah melakukan proses identifikasi, selanjutnya adalah proses analisis resiko. Pada tahap ini dilakukannya penilaian terhadap kemungkinankemungkinan resiko yang sudah di identifikasi pada proses sebelumnya dengan menggunakan tabel kriteria likelihood dan kriteria impact sebagai acuan untuk melakukan proses analisis resiko. Dapat dilihat pada tabel Likelihood.

Tabel 4. Likelihood

\begin{tabular}{|c|c|c|c|}
\hline \multicolumn{4}{|c|}{ Likelihood } \\
\hline Nilai & $\begin{array}{l}\text { Kriteri } \\
\text { a }\end{array}$ & Deskripsi & $\begin{array}{l}\text { Frekuens } \\
\text { i } \\
\text { kejadian }\end{array}$ \\
\hline 1 & Rare & $\begin{array}{l}\text { Resiko tersebut } \\
\text { hampir tidak } \\
\text { pernah terjadi }\end{array}$ & $>2$ tahun \\
\hline 2 & Unlikely & $\begin{array}{l}\text { Resiko tersebut } \\
\text { jarang terjadi }\end{array}$ & 1-2 tahun \\
\hline 3 & Possible & $\begin{array}{l}\text { Resiko tersebut } \\
\text { kadang terjadi }\end{array}$ & $\begin{array}{l}7-12 \\
\text { bulan }\end{array}$ \\
\hline 4 & Likely & $\begin{array}{l}\text { Resiko tersebut } \\
\text { sering terjadi }\end{array}$ & 4-6 bulan \\
\hline
\end{tabular}




\section{Journal of Computer and Information Systems Ampera}

Vol. 2, No. 2, May 2021 e-ISSN: 2775-2496

https://journal-computing.org/index.php/journal-cisa/index

Certain Resiko tersebut 1-3 bulan

pasti terjadi

Tabel 4 pada likelihood terdapat 5 kriteria berdasarkan kemungkinan resiko yang terjadi yaitu Rare merupakan resiko tersebut hampir tidak pernah terjadi lebih dari 2 tahun, Unlikely merupakan resiko yang jarang terjadi selama 1 sampai 2 tahun, Possible merupakan resiko yang kadang terjadi selama 7 sampai 12 bulan, Likely merupakan resiko yang sering terjadi selama 4 sampai 6 bulan, dan Certain merupakan resiko yang pasti terjadi selama 1 sampai 3 bulan.

Kriteria Impact merupakan tabel penilaian impact atau dampak yang akan terjadi jika kemungkinan-kemungkinan resiko terjadi di perusahaan. Pada Kriteria Impact terdapat 5 kriteria yang akan terjadi. Kriteria tersebut dibagi berdasarkan dampak yang tidak berpengaruh dan dampak yang paling berpengaruh dalam berjalannya proses bisnis perusahaan. Setelah kemungkinan resiko di identifikasi, selanjutnya adalah proses memasukan ke table impact sesuai dengan kriteria yang sudah ditentukan. Dapat dilihat pada tabel kriteria impact.

Tabel 5. Kriteria Impact

\begin{tabular}{|c|c|c|}
\hline \multicolumn{3}{|c|}{ Impect } \\
\hline Nilai & Kriteria & Keterangan \\
\hline 1 & $\begin{array}{l}\text { Insignifican } \\
t\end{array}$ & $\begin{array}{l}\text { Tidak mengganggu } \\
\text { aktivitas gereja }\end{array}$ \\
\hline 2 & Minor & $\begin{array}{l}\text { Tidak menghambat dan } \\
\text { mengganggu aktivitas } \\
\text { gereja }\end{array}$ \\
\hline 3 & Moderate & $\begin{array}{l}\text { Mengganggu proses } \\
\text { bisnis sehingga } \\
\text { mengakibatkan } \\
\text { terhambatnya aktivitas } \\
\text { gereja }\end{array}$ \\
\hline 4 & Major & $\begin{array}{l}\text { Hampir menghambat } \\
\text { seluruh jalannya } \\
\text { aktivitas gereja }\end{array}$ \\
\hline 5 & $\begin{array}{l}\text { Catastrophi } \\
\text { c }\end{array}$ & $\begin{array}{l}\text { Mengakibatkan aktivitas } \\
\text { terhenti karena proses }\end{array}$ \\
\hline
\end{tabular}




\section{Journal of Computer and Information Systems Ampera}

Vol. 2, No. 2, May 2021 e-ISSN: 2775-2496

https://journal-computing.org/index.php/journal-cisa/index

bisnis mengalami
gangguan total

Pada tabel 5 kriteria impact terdapat 5 kriteria yaitu Insignificant tidak mengganggu aktivitas gereja seperti beribadah, Minor tidak menghambat dan mengganggu aktivitas gereja seperti aktif dalam pelayanan gereja. Moderate mengganggu proses bisnis sehingga mengakibatkan terhambatnya aktivitas gereja seperti buat keributan di dalam gereja, Major hampir menghambat seluruh jalannya aktivitas gereja pemadaman listrik pada saat misa berlangsung, dan Catastrophic mengakibatkan aktivitas terhenti karena proses bisnis mengalami gangguan total seperti kegiatan yang berbau teroris (pengeboman) dan bencana alam (gempa bumi).

Setelah mendapatkan nilai kemungkinan likelihood dan dampak impact yang sudah ditentukan, maka selanjutnya akan dilakukan penilai terhadap kemungkinan-kemungkinan resiko yang ada pada aset terkait aplikasi Sistem Informasi Pengelolaan Data Umat yang sudah di identifikasi pada proses sebelumnya. Penilaian kemungkinan-kemungkinan resiko, dapat dilihat pada tabel penilaian kemungkinan risiko likelihood dan impact.

Tabel 6. Penilaian Kemungkinan Resiko Likelihood dan Impact

\begin{tabular}{llll}
\hline ID & Kemungkinan Resiko & Likelihood & Impect \\
\hline RE01 & Petir & 1 & 2 \\
RE02 & Banjir & 2 & 3 \\
RE03 & Kebakaran & 1 & 5 \\
RE04 & Gempa bumi & 1 & 5 \\
RE05 & Penyalahgunaan hak akses & 2 & 1 \\
RE06 & Perubahan data umat & 4 & 1 \\
RE07 & User interface aplikasi yang & 1 & 1 \\
& sulit dipahami & & \\
RE08 & Cybercrime & 2 & 2 \\
RE09 & Pencurian perangkat data & 2 & 2 \\
RE10 & Overload & 3 & 3 \\
RE11 & Overheat jaringan tidak & 3 & 3 \\
RE12 & Koneksi jari & 3 \\
& stabil & & \\
RE13 & Koneksi jaringan terputus & 3 & 4 \\
RE14 & Data corrupt & 1 & 2
\end{tabular}


Journal of Computer and Information Systems Ampera

Vol. 2, No. 2, May 2021 e-ISSN: 2775-2496

https://journal-computing.org/index.php/journal-cisa/index

\begin{tabular}{llll} 
RE15 & Backup failure & 1 & 1 \\
RE16 & Kerusakan hardware & 3 & 2 \\
\hline
\end{tabular}

Pada tabel 6 menunjukan setelah dimasukkannya 16 kemungkinan resiko yaitu: RE01 Petir didalamnya terdapat likelihood merupakan resiko tersebut hampir tidak pernah terjadi dan impact tidak menghambat dan mengganggu aktivitas gereja, RE02 Banjir didalamnya terdapat likelihood merupakan resiko tersebut jarang terjadi dan impact mengganggu proses bisnis sehingga mengakibatkan terhambatnya aktivitas gereja, RE03 Kebakaran didalamnya terdapat likelihood merupakan resiko tersebut hampir tidak pernah terjadi dan impact mengakibatkan aktivitas terhenti karena proses bisnis mengalami gangguan total, RE04 Gempa bumi di dalamnya terdapat likelihood resiko tersebut hampir tidak pernah terjadi dan impact mengakibatkan aktivitas terhenti karena proses bisnis mengalami gangguan total, RE05 Penyalahgunaan hak akses didalamnya terdapat likelihood merupakan resiko tersebut jarang terjadi dan impact tidak menghambat dan mengganggu aktivitas gereja, RE06 Perubahan data umat didalamnya terdapat likelihood resiko tersebut sering terjadi dan impact tidak mengganggu aktivitas gereja, RE07 User interface aplikasi yang sulit dipahami didalamnya terdapat likelihood merupakan resiko tersebut hampir tidak pernah terjadi dan impact tidak mengganggu aktivitas gereja, RE08 Cybercrime didalamnya terdapat likelihood merupakan resiko tersebut jarang terjadi dan impact tidak menghambat dan mengganggu aktivitas gereja.

RE09 Pencurian perangkat data didalamnya terdapat likelihood merupakan resiko tersebut jarang terjadi dan impact tidak menghambat dan mengganggu aktivitas gereja, RE10 Overload didalamnya terdapat likelihood merupakan resiko tersebut kadang terjadi dan impact mengganggu proses bisnis sehingga mengakibatkan terhambatnya aktivitas gereja, RE11 Overheat didalamnya terdapat likelihood merupakan resiko tersebut kadang terjadi dan impact mengganggu proses bisnis sehingga mengakibatkan terhambatnya aktivitas gereja, RE12 Koneksi jaringan tidak stabil didalamnya terdapat likelihood merupakan resiko tersebut kadang terjadi dan impact mengganggu proses bisnis sehingga mengakibatkan terhambatnya aktivitas gereja, RE13 Koneksi jaringan terputus didalamnya terdapat likelihood merupakan resiko tersebut kadang terjadi dan impact hampir menghambat seluruh jalannya aktivitas gereja, RE14 Data corrupt didalamnya terdapat likelihood merupakan resiko tersebut hampir tidak pernah terjadi dan impact tidak 


\section{Journal of Computer and Information Systems Ampera}

Vol. 2, No. 2, May 2021 e-ISSN: 2775-2496

https://journal-computing.org/index.php/journal-cisa/index

menghambat dan mengganggu aktivitas gereja, RE15 Backup failure didalamnya terdapat likelihood merupakan resiko tersebut hampir tidak pernah terjadi dan impact tidak mengganggu aktivitas gereja, dan RE16 Kerusakan hardware didalamnya terdapat likelihood merupakan resiko tersebut kadang terjadi dan impact tidak menghambat dan mengganggu aktivitas gereja.

Penilaian kemungkinan risiko likelihood dan impact sudah ditentukan level dari masing-masing kemungkinan resikonya mulai dari level 1 sampai level 5 selanjutnya dilakukan tahap evaluasi risiko. Pada tahap evaluasi resiko dari kemungkinan-kemungkinan resiko yang sudah dianalisis pada tahap sebelumnya, hasil dari identifikasi dimasuk ke dalam matrix evaluasi resiko berdasarkan kerangka kerja ISO 31000. Matix evaluasi resiko dibagi menjadi 3 berdasarkan level resiko (risk level) yaitu: low, medium, dan high. Kemungkinan resiko dari nilai likelihood dan nilai impact pada proses sebelumnya akan disesuaikan dengan matrix yang ada. Untuk melihat hasil penilaian dari likelihood dan impact, dapat dilihat pada Matrix Evaluasi Resiko berikut ini.

Table 7. Matrix Evaluasi Resiko

\begin{tabular}{|c|c|c|c|c|c|c|c|}
\hline \multirow{7}{*}{ 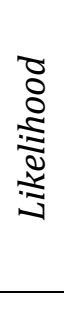 } & Certain & 5 & Medium & Medium & High & High & High \\
\hline & Likely & 4 & Medium & Medium & Medium & High & High \\
\hline & Possible & 3 & Low & Medium & Medium & Medium & High \\
\hline & Unlikely & 2 & Low & Low & Medium & Medium & Medium \\
\hline & Rare & 1 & Low & Low & Low & Medium & Medium \\
\hline & & & 1 & 2 & 3 & 4 & 5 \\
\hline & Impect & & Insignificant & Minor & Moderate & Major & Catastrophic \\
\hline
\end{tabular}

Tabel 7 menjelaskan tahap Matrik evaluasi resiko mulai dari likelihood ada 5 yaitu: Certain didalamnya terdapat likelihood, resiko tersebut sering terjadi dan evaluasi matriksnya masuk kategori sedang, likely didalamnya terdapat likelihood, resiko tersebut sering terjadi dan evaluasi matriksnya masuk kategori sedang, possible didalamnya terdapat likelihood resiko tersebut kadang terjadi dan evaluasi matriksnya masuk kategori rendah , unlikely didalamnya terdapat likelihood resiko tersebut jarang terjadi dan evaluasi matriksnya masuk kategori rendah, rare didalamnya terdapat likelihood resiko tersebut hamper tidak pernah terjadi dan evaluasi matriksnya masuk kategori rendah. Selanjutnya dari impact kita akan menentukan mulai dari 1 sama dengan Insignificant tidak mengganggu 


\section{Journal of Computer and Information Systems Ampera}

Vol. 2, No. 2, May 2021 e-ISSN: 2775-2496

https://journal-computing.org/index.php/journal-cisa/index

aktivitas gereja, 2 sama dengan Minor yaitu tidak menghambat dan mengganggu aktivitas gereja, 3 sama dengan Moderate yaitu mengganggu proses bisnis sehingga mengakibatkan terhambatnya aktivitas gereja, 4 sama dengan Major yaitu hampir menghambat seluruh jalannya aktivitas gereja, 5 sama dengan Catastrophic yaitu mengakibatkan aktivitas terhenti karena proses bisnis mengalami gangguan total. Setelah dilakukannya matrix evaluasi risiko berdasarkan identitas yang dimiliki oleh kemungkinan resikonya dan dimasukan pada matrix evaluasi sesuai dengan kriteria Likelihood and Impact.

Tabel 8. Matrix Evaluasi Resiko Berdasarkan Likelihood dan Impact

\begin{tabular}{|c|c|c|c|c|c|c|c|}
\hline \multirow{6}{*}{ 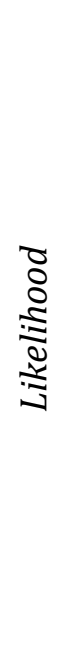 } & Certain & \multicolumn{2}{|l|}{5} & & \multicolumn{2}{|l|}{$\begin{array}{l}\text { RE12 } \\
\text { RE13 }\end{array}$} & \\
\hline & Likely & 4 & & $\begin{array}{l}\text { RE07 } \\
\text { RE06 } \\
\text { RE10 }\end{array}$ & & & \\
\hline & $\begin{array}{l}\text { Possible } \\
\text { Unlikely }\end{array}$ & 2 & RE11 & $\begin{array}{l}\text { RE16 } \\
\text { RE01 } \\
\text { RE05 } \\
\text { RE08 } \\
\text { RE09 }\end{array}$ & & & RE04 \\
\hline & Rare & 1 & RE15 & RE14 & RE02 & & RE03 \\
\hline & & & 1 & 2 & 3 & 4 & 5 \\
\hline & Impect & & Insignificant & Minor & Moderate & Major & Catastrophic \\
\hline
\end{tabular}

Tabel 8 menjelaskan bahwa setelah kemungkinan-kemungkinan resiko dimasukan kedalam matrik evaluasi berdasarkan likelihood dan impact, maka dibuat Level Risiko Berdasarkan Kemungkinan Resiko dikelompokkan menjadi 16 kemungkinan resiko dimasukan kedalam masing-masing level risiko dengan tingkat high, medium, dan low. Pada tingkat high ada RE12 ada koneksi jaringan tidak stabil, RE13 ada koneksi jaringan terputus, RE04 ada gempa bumi, tingkat medium ada RE07 ada user interface aplikasi yang sulit dipahami, RE06 ada perubahan data umat, RE16 ada kerusakan hardware, RE03 ada kebakaran, dan tingkat low ada RE11 ada overheat, RE01 ada petir, RE05 ada penyalahgunaan hak akses, RE08 ada cybercrime, RE09 ada pencurian perangkat data, RE14 ada data corrupt, RE15 ada backup failure, dan RE02 ada banjir. Untuk melihat level 


\section{Journal of Computer and Information Systems Ampera}

Vol. 2, No. 2, May 2021 e-ISSN: 2775-2496

https://journal-computing.org/index.php/journal-cisa/index

risiko berdasarkan kemungkinan resikonya dapat dilihat pada tabel level risiko berdasarkan kemungkinan.

Tabel 9. Level Risiko Berdasarkan Kemungkinan Resiko

\begin{tabular}{lllll}
\hline ID & Kemungkinan Resiko & Likelihood & Impact & Risk Level \\
& & & & \\
\hline RE12 & Koneksi jaringan terputus & 3 & 4 & High \\
RE13 & $\begin{array}{l}\text { Koneksi jaringan tidak } \\
\text { stabil }\end{array}$ & 3 & 3 & High \\
RE04 & Gempa Bumi & 1 & 5 & High \\
RE07 & User interface aplikasi & 1 & 1 & Medium \\
& yang sulit dipahami & & & \\
RE10 & Overload & 3 & 3 & Medium \\
RE03 & Kebakaran & 1 & 5 & Medium \\
RE16 & Kerusakan hardware & 3 & 2 & Medium \\
RE01 & Petir & 1 & 2 & Low \\
RE02 & Banjir & 2 & 3 & Low \\
RE09 & Pencurian perangkat data & 2 & 2 & Low \\
RE08 & Cybercrime & 2 & 2 & Low \\
RE11 & Overheat & 3 & 3 & Low \\
RE05 & Penyalahgunaan & 2 & 1 & Low \\
RE15 & Backup failure & 1 & 1 & Low \\
RE06 & Perubahan data umat & 4 & 2 & Low \\
RE14 & Data corrupt & 1 & & Low \\
\hline
\end{tabular}

Tabel 9 menghasilkan evaluasi resiko dapat dilihat pada Level Risiko Berdasarkan Kemungkinan Resiko, terdapat 16 kemungkinan resiko yang sudah dianalisis berdasarkan tingkat level resikonya. Terdapat 3 kemungkinan resiko yang masuk kedalam level of risk tingkat high yaitu Koneksi jaringan terputus untuk likelihood resiko tersebut kadang terjadi dan impact hampir menghambat seluruh jalannya aktivitas gereja, Koneksi jaringan tidak stabil untuk likelihood resiko tersebut kadang terjadi dan 


\section{Journal of Computer and Information Systems Ampera}

Vol. 2, No. 2, May 2021 e-ISSN: 2775-2496

https://journal-computing.org/index.php/journal-cisa/index

impact mengganggu proses bisnis sehingga mengakibatkan terhambatnya aktivitas gereja, dan Gempa Bumi untuk likelihood resiko tersebut hampir tidak pernah terjadi dan impactnya mengakibatkan aktivitas terhenti karena proses bisnis mengalami gangguan total.

Terdapat 4 kemungkinan resiko yang masuk ke dalam level of risk tingkat medium yaitu User interface aplikasi yang sulit dipahami untuk likelihood resiko tersebut hampir tidak pernah terjadi dan impact tidak mengganggu aktivitas gereja, Overload untuk likelihood resiko tersebut kadang terjadi dan impact mengganggu proses bisnis sehingga mengakibatkan terhambatnya aktivitas gereja, kebakaran untuk likelihood resiko tersebut hampir tidak pernah terjadi dan impact mengakibatkan aktivitas terhenti karena proses bisnis mengalami gangguan total, dan kerusakan hardware untuk likelihood resiko tersebut kadang terjadi dan impact tidak menghambat dan mengganggu aktivitas gereja. Serta terdapat 9 kemungkinan resiko yang masuk ke dalam level of risk tingkat low yaitu Petir untuk likelihood resiko tersebut hampir tidak pernah terjadi dan impact tidak menghambat dan mengganggu aktivitas gereja, Banjir untuk likelihood resiko tersebut jarang terjadi dan impact mengganggu proses bisnis sehingga mengakibatkan terhambatnya aktivitas gereja.

Pencurian perangkat data untuk likelihood resiko tersebut jarang terjadi dan impact tidak menghambat dan mengganggu aktivitas gereja, Cybercrime untuk likelihood resiko tersebut jarang terjadi dan impact tidak menghambat dan mengganggu aktivitas gereja, Overheat untuk likelihood resiko tersebut kadang terjadi dan impact mengganggu proses bisnis sehingga mengakibatkan terhambatnya aktivitas gereja, Penyalahgunaan hak akses untuk likelihood resiko tersebut jarang terjadi dan impact tidak mengganggu aktivitas gereja, Backup failure untuk likelihood resiko tersebut hampir tidak pernah terjadi dan impact tidak mengganggu aktivitas gereja , Perubahan data umat untuk likelihood resiko tersebut sering terjadi dan impact tidak mengganggu aktivitas gereja, dan Data corrupt untuk likelihood resiko tersebut hampir tidak pernah terjadi dan impact tidak menghambat dan mengganggu aktivitas gereja. Dari hasil analisis yang dilakukan dapat dilihat dari level of risk tingkat high, level of risk medium dan level of low, sudah kelihatan mana resiko yang tinggi, sedang, dan rendah berdasarkan kemungkinan resiko yang telah diteliti.

Selanjutnya dilakukan proses Perlakuan risiko. Dimana pada tahap ini akan diberi usulan-usulan atau tindakan terkait perlakuan kemungkinan- 


\section{Journal of Computer and Information Systems Ampera}

Vol. 2, No. 2, May 2021 e-ISSN: 2775-2496

https://journal-computing.org/index.php/journal-cisa/index

kemungkinan resiko yang sudah dikelompokkan. Agar dalam menjalankan proses bisnis dapat berjalan dengan lancar sesuai dengan SOP (Standar Operasional Prosedur) yang diterapkan perusahaan atau organisasi. Untuk perlakuan risiko dapat dilihat pada tabel usulan perlakuan risiko.

Tabel 10. Usulan Perlakuan Risiko

\begin{tabular}{|c|c|c|c|}
\hline ID & Kemungkinan Resiko & Risk Level & Tindakan Resiko \\
\hline RE12 & $\begin{array}{l}\text { Koneksi } \\
\text { terputus }\end{array}$ & High & $\begin{array}{lrr}\begin{array}{l}\text { Lapor } \\
\text { mantene }\end{array} & \text { bagian } \\
\text { perusahaan } & & \end{array}$ \\
\hline RE13 & $\begin{array}{l}\text { Koneksi jaringan tidak } \\
\text { stabil }\end{array}$ & High & $\begin{array}{l}\text { Mengganti ISP (Internet } \\
\text { service provider) yang } \\
\text { baru }\end{array}$ \\
\hline RE04 & Gempa Bumi & High & $\begin{array}{l}\text { Menyediakan server } \\
\text { cadangan di tempat yang } \\
\text { aman }\end{array}$ \\
\hline RE07 & $\begin{array}{l}\text { User interface aplikasi } \\
\text { yang sulit dipahami }\end{array}$ & Medium & $\begin{array}{l}\text { Membuat tampilan user } \\
\text { interface yang simple } \\
\text { dan membuat petunjuk } \\
\text { penggunaan aplikasinya. }\end{array}$ \\
\hline RE10 & Overload & Medium & $\begin{array}{lr}\text { Melakukan } & \text { refresh db } \\
\text { log, temp dan RAM } \\
\text { setelah itu lakukan } \\
\text { pengecekan } \\
\text { teratur secara } \\
\text { seminggu sekali agar } \\
\text { tidak } \\
\text { penumpukan masalah } \\
\text { pada aplikasi }\end{array}$ \\
\hline RE03 & Kebakaran & Medium & $\begin{array}{l}\text { Menyediakan server } \\
\text { cadangan di tempat yang } \\
\text { aman }\end{array}$ \\
\hline RE16 & Kerusakan hardware & Medium & $\begin{array}{l}\text { Melakukan perawatan } \\
\text { rutin terkait hardware }\end{array}$ \\
\hline RE01 & Petir & Low & $\begin{array}{l}\text { Memasang } \\
\text { penangkal petir pada } \\
\text { perusahaan }\end{array}$ \\
\hline
\end{tabular}


https://journal-computing.org/index.php/journal-cisa/index

\begin{tabular}{|c|c|c|c|}
\hline RE02 & Banjir & Low & $\begin{array}{lr}\text { Menyimpan } & \text { aset } \\
\text { perusahaan ditempat } \\
\text { yang lebih tinggi dan } \\
\text { memasang server } \\
\text { cadangan di tempat } \\
\text { tempat yang lebih aman }\end{array}$ \\
\hline RE09 & $\begin{array}{l}\text { Pencurian } \\
\text { data }\end{array}$ & Low & $\begin{array}{l}\text { Memasang cctv pada } \\
\text { ruangan yang penting } \\
\text { dan selalu melakukan } \\
\text { pengawasan }\end{array}$ \\
\hline RE08 & Cybercrime & Low & $\begin{array}{l}\text { Mengganti password } \\
\text { server secara berkala } \\
\text { dan memasang cctv pada } \\
\text { ruangan yang penting } \\
\text { dan selalu melakukan } \\
\text { pengawasan }\end{array}$ \\
\hline RE11 & Overheat & Low & $\begin{array}{l}\text { Mengontrol } \\
\text { ruangan agar selalu } \\
\text { dingin dan selalu } \\
\text { melakukan service AC } \\
\text { (air conditioner) } \\
\text { minimal seminggu sekali }\end{array}$ \\
\hline RE05 & $\begin{array}{l}\text { Penyalahgunaan hak } \\
\text { akses }\end{array}$ & Low & $\begin{array}{l}\text { Memberikan batasan } \\
\text { user pada aplikasi dan } \\
\text { memberikan konfirmasi } \\
\text { login pada bagian } \\
\text { pengelola IT }\end{array}$ \\
\hline RE15 & Backup failure & Low & $\begin{array}{l}\text { Mengontrol penggunaan } \\
\text { memory database } \\
\text { jangan sampai penuh } \\
\text { dan melakukan } \\
\text { maintenance secara } \\
\text { berkala }\end{array}$ \\
\hline RE06 & Perubahan data umat & Low & $\begin{array}{l}\text { Lapor atau konfirmasi } \\
\text { pada bagian IT yang } \\
\text { mengelola tentang data } \\
\text { umat }\end{array}$ \\
\hline
\end{tabular}


Journal of Computer and Information Systems Ampera

Vol. 2, No. 2, May 2021 e-ISSN: 2775-2496

https://journal-computing.org/index.php/journal-cisa/index

$\begin{array}{ll}\text { RE14 Data corrupt } \quad \text { Low } & \text { Melakukan backup } \\ & \text { secara berkala untuk } \\ \text { mengantisipasi } & \\ \text { kemungkinan yang } \\ \text { terjadi dan memproteksi } \\ \text { PC dengan antivirus } \\ \text { secara berkala untuk } \\ \text { mencegah munculnya } \\ \text { virus }\end{array}$

Pada tabel 10 menjelaskan bahwa Usulan perlakuan resiko sudah dijabarkan dari kemungkinan resiko, risk level dan tindakan resiko. Ditentukan mulai dari tinggi, sedang dan rendah kemungkinan resikonya mulai dari Koneksi jaringan terputus menyebabkan tingginya resiko dan tindakan yang dilakukan adalah lapor ke bagian maintenance jaringan perusahaan, Koneksi jaringan tidak stabil menyebabkan tingginya resiko dan tindakan yang dilakukan adalah mengganti ISP (Internet service provider) yang baru agar stabil kembali jaringannya, Gempa Bumi menyebabkan tingginya risiko dan tindakan yang dilakukan adalah menyediakan server cadangan ditempat yang aman, User interface aplikasi yang sulit dipahami menyebabkan resiko sedang yang terjadi dan tindakan yang dilakukan adalah membuat tampilan user interface yang simple dan membuat petunjuk penggunaan aplikasinya.

Overload menyebabkan resiko sedang,dan tindakan yang dilakukan adalah melakukan refresh $d b \log$, suhu dan RAM (Random Access Memory) setelah itu lakukan pengecekan secara teratur minimal seminggu sekali agar tidak adanya penumpukan masalah pada aplikasi, Kebakaran menyebabkan resiko sedang dan tindakan yang dilakukan adalah menyediakan server cadangan ditempat yang aman, Kerusakan hardware menyebabkan resiko sedang dan tindakan yang dilakukan adalah melakukan perawatan rutin terkait hardware, Petir menyebabkan rendahnya resiko dan tindakan yang dilakukan adalah memasang alat penangkal petir pada perusahaan, Banjir menyebabkan rendahnya resiko dan tindakan yang dilakukan adalah menyimpan aset perusahaan ditempat yang lebih tinggi dan memasang server cadangan di tempat tempat yang lebih aman, Pencurian perangkat data menyebabkan rendahnya resiko dan tindakan yang dilakukan adalah memasang cctv pada ruangan yang penting dan selalu melakukan pengawasan. 
https://journal-computing.org/index.php/journal-cisa/index

Cybercrime menyebabkan rendahnya resiko dan tindakan yang dilakukan adalah mengganti password server secara berkala dan memasang cctv pada ruangan yang penting dan selalu melakukan pengawasan, Overheat menyebabkan rendahnya resiko dan tindakan yang dilakukan adalah mengontrol suhu ruangan agar selalu dingin dan selalu melakukan service AC (air conditioner) minimal seminggu sekali, Penyalahgunaan hak akses menyebabkan rendahnya resiko dan tindakan yang dilakukan adalah memberikan batasan user pada aplikasi dan memberikan konfirmasi login pada bagian pengelola IT, Backup failure menyebabkan rendahnya resiko dan tindakan yang dilakukan adalah mengontrol penggunaan memori database jangan sampai penuh dan melakukan maintenance secara berkala, Perubahan data umat menyebabkan rendahnya resiko dan tindakan yang dilakukan adalah lapor atau konfirmasi pada bagian IT yang mengelola tentang data umat, dan Data corrupt menyebabkan rendahnya resiko dan tindakan yang dilakukan adalah melakukan backup secara berkala untuk mengantisipasi kemungkinan yang terjadi dan memproteksi PC dengan antivirus secara berkala untuk mencegah munculnya virus.

\section{KESIMPULAN}

Kesimpulannya adalah terhambatnya proses bisnis membuat terhentinya pelayanan di dalam mengelola data umat, susahnya mencari informasi terkait data umat, tidak adanya data terbaru akan berdampak juga untuk bidang yang ada di Gereja Santo Paulus Miki Salatiga dan kurangnya sumber daya manusia yang mengelola aplikasi di Gereja Santo Paulus Miki Salatiga membuat proses bisnis tidak berjalan dengan lancar, mengatasi permasalahan dilakukannya Analisis Resiko Aplikasi Sistem Informasi Pengelolaan Data Umat Menggunakan ISO 31000 untuk melihat kemungkinan resiko yang membuat terhentinya proses bisnis, analisis yang dilakukan ada 2 tahap pencarian informasi yaitu Risk Assessment (Penilaian Resiko) dan Risk Treatment (Perlakuan Risiko. Pada tahap penilaian risiko melihat resiko apa saja yang akan muncul setelah itu susun strategis bagaimana cara agar tepat sasaran dan buat perbaiki jika gagal melakukan penilaian risiko. Tahap perlakuan risiko adalah merubah kemungkinan resiko yang akan terjadi sehingga perusahaan atau organisasi sudah mempunyai cadangan sebelum resiko terjadi dan tidak menghambat proses bisnis sehingga dapat berjalan dengan lancar. 
https://journal-computing.org/index.php/journal-cisa/index

\section{DAFTAR PUSTAKA}

[1] M. Miftah Khatun, "Analisis Manajemen Risiko Teknologi Informasi pada Website Echofon Menggunakan ISO 31000," J. Comput. Sci. Eng., vol. 1, no. 2, pp. 128-146, 2020, doi: 10.36596/jcsev1i2.76.

[2] A. R. Viyanto, O. S. Latuihamallo, F. M. Tua, and A. Gui, "Studi Kasus Pada Perusahaan Jasa," vol. 4, pp. 43-54, 2013.

[3] A. Novia Rilyani, Y. A. Firdaus W ST, and D. S. Dwi Jatmiko, "Analisis Risiko Teknologi Informasi Berbasis Risk Management Menggunakan ISO 31000 (Studi Kasus: i-Gracias Telkom University) Information Technology Risk Analysis Based on Risk Management Using Iso 31000 (Case Study: i-Gracias Telkom University)," e-Proceeding Eng., vol. 2, no. 2, pp. 6201-6208, 2015.

[4] R. P. Pangestu and A. F. Wijaya, "View of Analisis Management Resiko Aplikasi SINTESA Pada Perpustakaan XYZ," vol. 2, no. 2, pp. 1-14, 2020, [Online]. Available: http://journal.binadarma.ac.id/index.php/binakomputer/article/ view/804/529.

[5] G. W. Lantang, A. D. Cahyono, and M. N. N. Sitokdana, "Analisis Risiko Teknologi Informasi Pada Aplikasi Sap Di Pt Serasi Autoraya Menggunakan Iso 31000," Sebatik, vol. 23, no. 1, pp. 36-43, 2019, doi: $10.46984 /$ sebatikv23i1.441.

[6] F. L. Nice and R. V. Imbar, "Analisis Risiko Teknologi Informasi pada Lembaga Penerbangan dan Antariksa Nasional (LAPAN) pada Website SWIFTS Menggunakan ISO 31000," J. Inform. dan Sist. Inf., vol. 2, no. 2, pp. 1-11, 2017.

[7] F. M. Hutabarat and A. D. Manuputty, "Analisis Risiko Teknologi Informasi Aplikasi VCare PT Visionet Data Internasional Menggunakan ISO 31000," J. Bina Komputer., vol. 2, no. 1, pp. 52-65, 2020, doi: 10.33557/binakomputer.v2i1.792.

[8] N. U. Handayani, D. P. Sari, D. O. Irawan, and Z. Afdi, "Departemen Teknik Industri Universitas Diponegoro," vol. XII, no. 1, 2017.

[9] H. T. I. Driantami, Suprapto, and A. R. Perdanakusuma, "Analisis Risiko Teknologi Informasi Menggunakan ISO 31000 (Studi kasus: Sistem Penjualan PT Matahari Department Store Cabang Malang Town Square)," J. Pengemb. Teknol. Inf. dan Ilmu Komputer., vol. 2, no. 11, pp. 4991-4998, 2018.

[10] K. B. Mahardika, A. F. Wijaya, and A. D. Cahyono, "Manajemen Risiko Teknologi Informasi Menggunakan Iso 31000: 2018 (Studi Kasus: Cv. Xy)," Sebatik, vol. 23, no. 1, pp. 277-284, 2019, doi: 


\section{Journal of Computer and Information Systems Ampera}

Vol. 2, No. 2, May 2021 e-ISSN: 2775-2496

https://journal-computing.org/index.php/journal-cisa/index

10.46984/sebatik.v23i1.572.

[11] G. H. S. Rampini, H. Takia, and F. T. Bersanetti, "Critical success factors of risk management with the advent of ISO 310002018 Descriptive and content analyzes," Procedia Manuf., vol. 39, pp. 894-903, 2019, doi: 10.1016/j.promfg.2020.01.400.

[12] I. P. A. E. Pratama and M. T. S. Pratika, "Manajemen Risiko Teknologi Informasi Terkait Manipulasi dan Peretasan Sistem pada Bank XYZ Tahun 2020 Menggunakan ISO 31000:2018," J. Telemat., vol. 15, no. 2, pp. 63-70, 2020.

[13] Sermon Paskah Zagato and Melkior N. N. Sitokdana, "Analisis Risiko Teknologi Informasi Di Organisasi Xyz Cabang Salatiga Menggunakan Iso 31000," J. Mnemon., vol. 4, no. 1, pp. 1-9, 2021, doi: 10.36040/mnemonic.v4i1.2877.

[14] G. Mochammad Husein and R. V. Imbar, "Analisis Manajemen Risiko Teknologi Informasi Penerapan Pada Document Management System di PT. JABAR TELEMATIKA (JATEL)," J. Tek. Inform. dan Sist. Inf., vol. 1, no. 2, pp. 75-87, 2015, doi: 10.28932/jutisi.v1i2.368.

[15] A. Imansari, "Analisis Risiko Berdasarkan Aspek Waktu Dengan Metode Monte Carlo Pada Proyek Gedung Baru Di Universitas Brawijaya," Naskah Terpublikasi Tek. Sipil, 2019. 